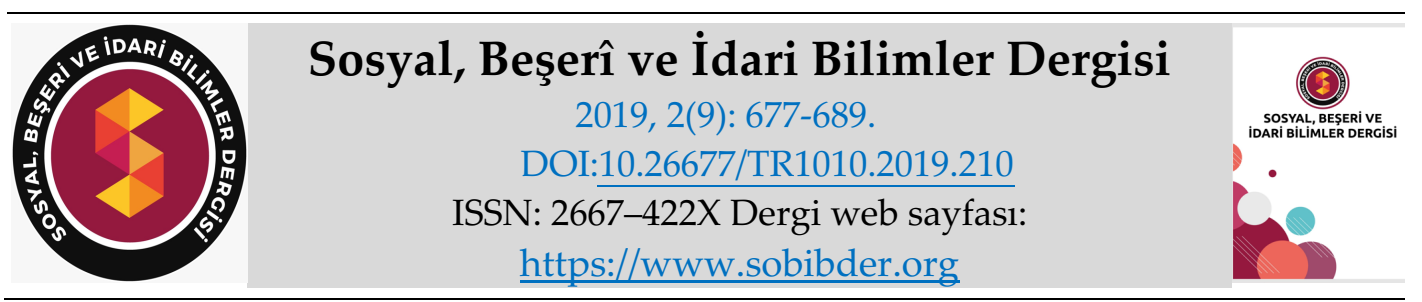

KAVRAMSAL MAKALE

\title{
Suyun Fiyatlandırmasında Erdemli Mal Yaklaşımı: Türk Toplumunun Algısı*
}

Dr. Öğr. Üyesi Murat AYDIN, Uşak Üniversitesi, Uygulamalı Bilimler Yüksekokulu, Uşak, eposta: murat.aydin@usak.edu.tr

ORCID: https://orcid.org/0000-0002-7211-5208

Doç. Dr. Abdülkerim ÇALIŞKAN, Afyon Kocatepe Üniversitesi, İ.̇̇.B.F, Afyonkarahisar, e-posta: abdulkerimc@hotmail.com

ORCID: https://orcid.org/00003-3123-8890

Öz

Su doğal bir kaynak olmasına rağmen, sonsuz değildir. Ayrıca kirlenmeye müsait ve kullanılabilir özellikleri hızla kaybolmaya müsait kıt bir maldır. Dünyadaki tatlı su miktarı nüfus artışı, kaynakların kirlenmesi ve yanlış kullanımı ile daha da kıt hale gelmiştir. Bütün bu sorunlar dünya ülkelerinde su yönetimi konusunda önemli tartışmaları beraberinde getirmiştir. Suyun sınıflandırılmasında iki ekol bulunmaktadır. İlk ekol, suyu özel mal olarak kabul eder. Su kıt bir kaynak olduğu için, fiyatlandırma mekanizmasının mutlaka kullanılması gerektiğini iddia etmektedirler. İkinci ekol ise tüm insanların suya erişim hakkına sahip olduğunu savunur. İnsanların, hayatlarını devam ettirmeleri açısından asgari miktara ulaşması gerekmektedir. Çalışmanın amacı, Türk Toplumu'nun bu sorunla ilgili algılarını ortaya koymaktır. Araştırmada derinlemesine görüşme tekniği uygulanmıştır. Kolayda örnekleme yöntemiyle Ankara, İzmir, Manisa, Uşak, Afyon'da yaşayan 150 katılımcıya ulaşılmıştır. Tüm katılımcılar suya erişimin bir insan hakkı olduğu belirtmişlerdir. Araştırmada suyun özel mallar gibi piyasa koşullarında fiyatlandırılmasının etik olmadığı sonucuna varılmıştır. Bunun yerine, su kullanımında israfı önleyecek bir fiyatlandırma mekanizmasının uygulanması gerektiği ortaya konmuştur.

*Bu çalışma 19-21 Nisan 2018 tarihinde Demre, Antalya' da düzenlenen "II. International Applied Social Sciences Congress" isimli kongrede sözlü olarak sunulmuştur.

Anahtar Kelimeler: Erdemli Mallar, Suyun Fiyatlandırılması, İnsan Hakkı

Makale Gönderme Tarihi: 14.04.2019

Makale Kabul Tarihi: 27.09.2019

\section{Önerilen Atıf:}

Aydın, M. ve Çalışkan, A. (2019). Suyun Fiyatlandırmasında Erdemli Mal Yaklaşımı: Türk Toplumunun Alg1sı, Sosyal, Beşeri ve İdari Bilimler Dergisi, 2(9): 677-689.

(c) 2019 Sosyal, Beşerî ve İdari Bilimler Dergisi. 


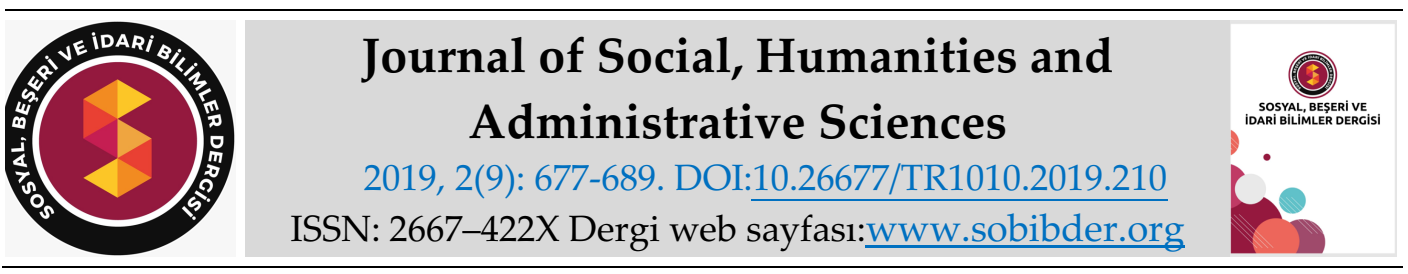

CONCEPTUAL PAPER

\title{
Merit Goods Approach in Water Pricing: Perception of Turkish Community
}

Assistant Prof. Dr. Murat AYDIN, Uşak University, School of Applied Sciences, Uşak, e-mail: murat.aydin@usak.edu.tr

ORCID: https://orcid.org/0000-0002-7211-5208

Associate Prof. Dr. Abdülkerim ÇALIŞKAN, Afyon Kocatepe University, Faculty of Economics and Administrative Sciences, Afyonkarahisar, e-mail: abdulkerimc@hotmail.com

ORCID: https://orcid.org/00003-3123-8890

\begin{abstract}
Although water is a natural source, it is not endless. Furthermore, it is available to be polluted, and its usable properties are quickly lost. The amount of fresh water in the world have become a scarce resource with population growth, pollution of resources and mishandling. All these problems have brought important discussions on water management in the world countries. There are two ecols of water classification. The first ecol accepts water as special goods. Since the water is a scarce resource, it means that the pricing mechanism must be used with absolute ease. Second ecol defends that all people have right of access to water. Water is a merit goods that must be reached to the minimum quantity for enable people to spend their lives. The aim of the study is to show perceptions of Turkish Community about this problem. In-depth interviewing technique has applied in the study. With convenience sampling method, it has been reached to 150 participants who live in Ankara, İzmir, Manisa, Uşak, Afyon. All of the participants have been indicated that access to the water is a human right. In the study, it has been concluded that water pricing is not ethical in the market conditions like special goods. Instead, it has been demonstrated that a pricing mechanism should be implemented to prevent wastage in water use.
\end{abstract}

Keywords: Merit Goods, Water Pricing, Human Right

Received: 14.04 .2019

Accepted: 27.09.2019

\section{Suggested Citation:}

Aydın, M. and Çalışkan, A. (2019). Merit Goods Approach in Water Pricing: Perception of Turkish Community, Journal of Social, Humanities and Administrative Sciences, 2(9): 677-689.

(c) 2019 Sosyal, Beşerî ve İdari Bilimler Dergisi. 


\section{Gíriş}

$\mathrm{Su}$, insan hayatının devamı için "olmazsa olmaz" derecede kıymetli bir kaynaktır. Yaşamsal işlevlerin gerçekleşmesinde en çok gereksinim duyulan doğal bir kaynak olup, yeryüzündeki canlılar için vazgeçilmez bir unsurdur. Dünyanın 3/4'ü sularla kaplı olmasına karşın, tatlı su miktarı \%0,74'tür (Akın vd., 2007: 107). Tatlı su; nüfusun artması ile birlikte talebin artması, su kaynaklarının kirletilmesi ve kötü yönetilmesinden dolayı daha da kıt bir kaynak haline gelmektedir. Ayrıca bu olumsuzluklara suyun küremizde eşit dağılmaması da eklenince, su yönetimi, çağımızın en önemli sorunlarından biri olarak görülmektedir. Su, sonsuz bir kaynak olmayıp, kirlenmeye müsait, kullanılabilir özelliklerini çabuk kaybeden doğal bir kaynaktır.

Dünya'da birçok ülke su sıkıntısı çekmektedir. Halen 1,2 milyar insan sağlıklı suya erişemezken, 2,4 milyardan fazla insan da hijyen koşullarına uygun suya erişememektir (Kaya, 2014: 55-75). Ülkemiz su sıkıntısı çeken ülkeler arasında yer almasa da artan nüfus, tehdit edici bir unsur olarak kapımızı çalmaktadır. Kentleşme ve sanayileşmeye bağlı olarak artan su talebi dikkate alındığında, yenilenebilir su kaynaklarında bir azalma ile karşılaşıldığı gözlenmektedir. Bu durum su kaynaklarının korunması gerektiğini ortaya koymaktadır. Unutulmamalıdır ki su aynı zamanda, gerekli ve yeterli miktarda, sağlık ve hijyen standartları altında temin edilmesi gereken, tüketilmesinin fiyat ya da kıtlık nedeniyle belli bir düzeyin altına inmesi durumunda kitlesel bulaşıcı hastalıkların ve sağlık sorunlarının baş göstereceği negatif dışsallıkların önlenmesi gereken bir maldır.

Çalışmada kentsel içme suyunun nasıl bir mal ve hizmet olduğu konu edilmektedir. Yani şebekeler ile meskenlere tedarik edilen içme suyunun kamusal bir mal olup olmadığı bu çalışmada irdelenmiştir. Ayrıca içme suyu fiyatlandırılırken hangi kriterlerin baz alınması gerektiği bu çalışmada tartışılmıştır. Zira su bazı ülkeler ve kuruluşlar tarafından ekonomik bir olarak kabul edilmekte ve kar amacı ön planda tutulmaktadır. Bazı ülkeler ise içme suyunun bir hak olarak kabul ettikleri için ücretsiz olarak sunmaktadirlar.

Bu çalışmada derinlemesine görüşme yöntemi kullanılmıştır. Ankara, İzmir, Manisa, Uşak ve Afyonkarahisar illerinde yaşayan 150 kişiye ulaşılmıştır. Kolayda örnekleme yolu ile seçilen katılımcılara 5 temel soru yöneltilmiştir. Katılımcıların içme suyu hakkındaki görüşleri tespit edilmiştir. İçme suyunu insan hakları kapsamında değerlendirdikleri, belediyelerin sunduğu içme suyu hizmetinin kamusal mal niteliğinde görülmesi gerektiği ve suyun bir bedel karşılığı verilmesinin daha uygun olacağını düşündükleri görülmüştür.

\section{İÇM SUYUNUN TASNIF SORUNU}

İçme suyunun nasıl bir mal olduğu noktasında tam bir uzlaşma sağlanamamakla birlikte, dünya devleri, suyun ekonomik bir meta olarak görülmesini istemektedirler (Diler, 2008:23). 1992 yılında düzenlenen Dublin Konferansında, suya ilk kez, "ekonomik mal" tanımlaması yapılmıştır (Zaag, 2002:98-104). Suyun, ekonomik meta olarak görülmesi kıt bir kaynak olmasından kaynaklanmaktadır. Suyun tasnifi açısından bir 
kırılma noktası olan Dublin Beyanı, su talep yönetiminde 4 prensip öne sürmektedir (Solanes, 1999:17). Bu prensipler, artan dünya nüfusuna karşın, hızla kirlenen temiz su kaynaklarının, nasıl yönetilmesi gerektiği ile ilgili alternatifler sunmaktadır.

Su ve su gibi doğal kaynaklar, 20. yüzyılın sonuna kadar, ortak mal veya kamu malı olarak görülmekte idi (Atvur, 2013). Ticarete konu olmayan bu gibi mallar, Roma Hukukunda "res publica" olarak adlandırılmış, genel kamu çıkarını koruyacak kurallarla düzenlenmesi gerektiği vurgulanmıştır. Esasen terminolojik bir ayrılık vardır (Vander, 2000:47-63). Bu ayrılıklar suyun tasnifi konusunda, iki ekolü doğurmuştur. İlk ekole göre; su kıt bir kaynak olduğu için, fiyatlandırma yoluyla suyun talebi yönetilmelidir. İkinci ekol, suyun kit bir kaynak olduğunu kabullenmekle birlikte, talebi yönlendirmek için suyu ekonomik bir mal olarak görmeye gerek olmadiğını savunmaktadır. Dolayısıyla fiyatlandırma aracinın kullanılmasını uygun görmemektedir.

\section{Temel Hak Bağlamında İçme Suyu (Kamu Yönetimi Yaklaşımı)}

Türk Dil Kurumu hak kavramını birkaç şekilde tanımlamıştır. Birinde, "Adaletin, hukukun gerektirdiği veya birine ayırdığ1 şey, kazanç" şeklinde, diğerinde, "Emek karşılığ 1 ücret" şeklinde tanımlamıştır. Anayasamızın ikinci kısmında, temel hak ve ödevlerden bahisle, kişi hakları, sosyal ekonomik ve siyasi haklar tanımlanmıştır. Madde 12'de temel hak ve hürriyetler başlığında, "Herkes, kişiliğine bağlı, dokunulmaz, devredilmez, vazgeçilmez temel hak ve hürriyetlere sahiptir."

Genel kabul görmüş toplumsal sözleşme niteliği taşıyan "İnsan Hakları Evrensel Beyannamesi ${ }^{1 "}$ nde suyun temel haklardan olduğuna dair, belirgin bir ifade bulunmamaktadır (Kartal, 2006:478-485). Ancak, 3. maddesinde "Yaşamak, özgürlük ve kişi güvenliği herkesin hakkıdır" ifadesiyle, suya erişimin, dolayısıyla yaşamak hakkına girdiği söylenebilmektedir. Her ne kadar suyun ekonomik bir değeri olduğu kabul edilse de, suya erişmenin de insanın hakkı olduğu da, uluslararası platformlarda dillendirilmeye başlanmıştır (Irujo, 2007:267-283). Başta Dünya Sağlık Örgütü (WHO) olmak üzere, pek çok uluslararası kuruluş, insanın susuzluktan ve susuzluğa bağlı hastalıklardan ölmeyecek minimum seviyede suya ulaşmasının gerektiğini kabul etmektedirler (Gleick, 1993:79-112).

Esasen, suyu hak olarak görenler, insanın, yaşamını sağlıklı bir şekilde sürdürebilmesi için temiz suya mutlaka ulaşması gerektiğini savunmaktadırlar. Yukarıda da belirtildiği gibi, minimum düzeyde bu miktar 25 litredir (Çiçek, 2009:184). Kentsel şebeke suyu, salt özel mal olarak yönetilirse, suya ulaşım maliyeti ciddi boyutlarda artış gösterecek, İngiltere'de olduğu gibi "su yoksulları" ortaya çıkacaktır (Görer, 2001:26). İngiltere'de, içme suyunu özel sektörün vermesi ile su faturalarında ortalama \%31'lik bir artış meydana gelmiştir.

Ülkemizde içme suyu ve kanalizasyon hizmetleri belediyeler tarafından, yani kamu sektörünce sunulmaktadır. Her ne kadar kalkınma planlarında, ileriki yıllarda bu

\footnotetext{
${ }^{1}$ http://www.tbmm.gov.tr/komisyon/insanhaklari/pdf01/203-208.pdf-Erişim Tarihi(18.02.2015)
} 
hizmetlerin özel sektöre devri planlansa da, ülkemiz bu hizmetlerin, tek amacı kar olan özel şirketler tarafından sunulmasına hazır değildir. 1993 yılında Antalya Büyükşehir Belediyesinin, içme suyu ve kanalizasyon hizmeti sunumunu yabancı bir şirkete devretmesi, bu şirketin en fazla 6 yıl devam edip tekrar belediyeye bırakması önemli bir delildir (Çalcalı, 2014).

\section{Ekonomik Açıdan İçme Suyu (Piyasacı Yaklaşım)}

Gereksinim (Güzelsarı ve Tuluay, 2011) gibi görülse de kıt bir kaynak olduğu için su, her geçen gün daha da kıymetlenmektedir. Kıt kaynakların idareli kullanılması esastır. Bu noktada aşırı talebi kısmak için, fiyat mekanizmasına ihtiyaç duyulmaktadır. Zira uluslararası otoritelerin son otuz-kırk yılda, suyun tasnifinde değişen görüşleri bunun göstergesidir. 1972 yılında Stockholm Deklarasyonunda suyun doğal bir kaynak olduğu, korunması gerektiği ve kamusal mal olduğu belirtilmiştir (Aykan, 2006:366). Yirmi yıl sonra, Dublin Beyanında suyun ekonomik değeri olduğu ve ekonomik mal olarak ele alınması gerektiği vurgulanmıştır. Aynı yıl Rio Deklarasyonu ve Gündem 21'de suyun sosyo-ekonomik yönünün de göz ardı edilmemesi gerektiği belirtilmiştir. Dünya Bankası adeta noktayı koymuş, suyun özelleştirilmesi ve içme suyu hizmetinin kamunun elinden alınmasının gerekliliğini savunmuştur (Aykan, 2006).

Değişen dünyada, suyun ekonomik bir mal gibi görülmeye başlanmasındaki temel sebeplerden birisi; Dublin deklarasyonunda, suyun bazı özelliklerinin belirtilmemesidir (Biswas, 1997:141-168). Deklarasyonun, hakkaniyet ve bölgesel gelir dağılımı gibi suyla ilgili temel kavramları dikkate almaması, ekonomik bakış açısını güçlendirmiştir. Diğer bir sebep de, kıt bir kaynak olan suyun israfını önlemektir. Tatlı su kaynaklarının israf edilmesi, gelecek nesiller açısından hiç de istenilen bir durum değildir. Bu gibi sebepler, suya ekonomik bir mal hüviyetini kazandırmaktadır. Kaldı ki su, kamusal mal statüsünde kalsa bile, kamu-özel ortak politikalarıla ekonomik bir mal gibi yönetilmesi mümkün görülmektedir (Atvur, 2013).

Küresel su tartışmalarının temelinde, suyu salt ortak mal veya salt özel mal olarak görme isteği yatmaktadır. İki ekol, suyun statüsü konusunda uzlaşma sağlayamamışlardır. Zira su ilk akıma göre, temel hak olduğu için, tüketiminde rekabeti netice verecek politikalardan kaçınılmalıdır. Her insan, yaşamını sürdürecek kadar suya erişebilmelidir. İkinci akım ise, hızla tükenen temiz su kaynaklarının, fiyatlandırma yöntemiyle dengeli ve israfsız kullanımına zemin hazırlayacak politikaların hayata geçirilmesini istemektedir. Son yıllarda, uluslararası konferanslar, zirveler ve su forumlarında, ikinci akımın kuvvetlendiği görülmektedir.

1990 yıllına kadar Dünya Bankası, çok büyük yatırımlar gerektirdiği için, içme suyu temin ve sanitasyon ${ }^{2}$ hizmetlerinde tek aktör kamu sektörü olmasının gerektiğini iddia ederken, özellikle 2000 yılından sonra, çok uluslu şirketler yoluyla, özel sektörün de, içme suyu temininde pay sahibi olmasını istemektedir (Castro, 2008:63).

\footnotetext{
${ }^{2}$ Çevre koşullarını sağlığa elverişli duruma getirme, sağlıklı yaşam için gerekli önlemleri alma, çevre hijyeni.
} 


\section{IÇME SUYUNUN DOĞAL TEKEL YÖNÜ}

Üretim, iletim ve ticaretindeki teknoloji, o hizmetin doğal tekel kabul edilmesindeki en temel etkendir (Ataay, 2003:34). Su - kanalizasyon, elektrik, doğalgaz, köprü, telekomünikasyon, demiryolu, liman ve havalimanı gibi hizmetler, doğası gereği tekel niteliktedir. Bu hizmetlerin sunumu belirli bir iletim ve boru hattı ile sağlanabilmektedir. Ayrıca doğal tekel mahiyetindeki bu hizmetlerin 3 özelliği bulunmaktadır (Ataay, 2003:34). Birincisi; birden fazla şirketin aynı anda hizmet verebilmesi için, farklı hatlar kurması gerekir, bu ise ekonomik verimlilik açısından israfa neden olur. Diğer özelliği; teknolojinin niteliği ancak tek firma ile verimliliği maksimum düzeye taşıyacaktır. Son olarak; bu tip kamu tekeli pozisyonundaki hizmetlerin toplumun tüm kademelerine ulaşması gerekmektedir. Zira tersi durumda, mesela toplumda su ve elektrik hizmetine ulaşamayanların varlığı, o toplum adına gelişmişlik ve refah adına kötü bir durum olacaktır.

İçme suyu ve sanitasyon (kanalizasyon ve katı atık) hizmetleri şebeke gerektiren doğal tekel hizmetlerdir (Çakal, 1996). Şebeke ise; önemli miktarda ilk yatırım gerektiren, sabit maliyetleri çok olan, elektrik, doğalgaz ve su gibi hizmetlerin bulunduğu piyasalardır (Tepe ve Ardiyok, 2004:115).

Daha önce de belirtildiği gibi, suyu salt özel, salt kamusal mal gibi görmek, sorunu çözmekten çok uzak iki yaklaşımdır. Burada önemli olan, hangi yönünün daha ağır bastığıdır. Zira neo liberallere göre; tam kamusal mal olması için, tüketiminden kimsenin dışlanmaması ve fiyatlandırılmaması gerekmektedir ki bu yönü ile içme suyu özel maldır (Bakker, 2007:435). Suyun bu iki karakteristiğine bakıp hükmedenler suyu bir hak olarak ta görmemektedirler. Elbette kamunun mülkiyetinde olması onu, kamusal mal yapmayacağı da bilinmelidir. Ancak bir mal ne kadar çok kamusalsa, o hizmeti kamunun sunması daha iyidir.

İçme suyu şebeke hizmetlerinin kamusal mal hüviyetinde olduğunu savunanların gerekçelerinin en önemlisi, bu hizmetin doğal tekel oluşudur. Doğal tekel; artan maliyetlerin çok önemli olduğu ve sektörde sadece tek firmanın olduğu sanayilerdir. Nitekim doğal tekeller, devletin ekonomiye müdahalesi veya doğrudan girmesi noktasında önemli sebeplerden birisidir. Doğal tekel piyasasında tüketicinin dışlanması devlet adına kötü bir durumdur. O halde dişlama sınırlı olacaktır.

Bir insanın, yetecek kadar suya ulaşması ve bu noktaya kadar dışlanmaması, içme suyunu erdemli mal sınıfına dâhil edecektir. Çünkü erdemli mallar da devletin ekonomiye müdahalesini meşru kılan durumlardan birisi olmakla birlikte, tüketimi kamu otoritesi tarafından özendirilen mallardır. Temel insani gereksinim yönüyle, insanların suya erişmelerinin kamusal tarafının ağır basmasıyla kamu otoritesinin sunumuna konu olabilecekken, zaruri su kullanım miktarından sonraki hizmet sunumu özel mal olarak değerlendirilebilecektir (Gökdemir, 2008). Bu bağlamda, içme suyu ve kanalizasyon hizmeti, bazı yönleriyle özel mal iken, daha önemli tarafları ile kamusal maldır.

Sosyal mallar, üç gruba ayrılmaktadır (Akalın, 2003:42-43).

- Salt sosyal mallar 
- Karma mallar

- Erdemli mallar

Erdemli mallar kişisel mal niteliğine sahip, tüketimleri engellenebilir hatta tayınlanabilen mallardır. Eğer erdemli malların üretimi piyasaya bırakılsa, yeteri kadar tüketilmeyecek ve negatif dışsallığa neden olacaklardır. Bunun için merit mallar kamu bütçesince finanse edilirler. Su, mahrumiyetinden dolayı, insanların hastalanması ve topluma zarar vermeleri yönüyle, asgari seviyede her insanın kullanması gereken erdemli bir maldır.

\section{IÇME SUYUNDA FIYATLANDIRMA(MA) ÇELIŞKKISI}

Kamu kesimince gerçekleştirilen altyapı hizmetleri, uzun vadeli, büyük bütçeli ve başlandığında vazgeçme maliyetleri çok yüksek yatırımlardır. İçme suyu ve atık su hizmetini sunmak, hijyeni sağlamak ve devam ettirmek, dünyada birçok metropol şehrin en önemli sorunlarındandır. ${ }^{3}$ Doğal tekel olan bu hizmetlerin hem altyapısını hazırlamak hem de işlerlik kazandırmak, kamu otoritesi açısından çok fazla sıkıntı olmayacaktır. Çünkü altyapı hizmetlerinin fiyatlandırması yapılırken, sosyal fayda, sosyal maliyet, parasal fayda ve parasal olmayan fayda gibi etkenler dikkate alınır. Sübvansiyon bu çeşit kamu kesiminin sunduğu hizmetler için vazgeçilmez bir unsurdur.

İçme suyunun fiyatlandırılması, iki açıdan sorun teşkil etmektedir. Birincisi; kamu sektörü, kıt bir kaynak olan suyun yönetiminde fiyatlandırma problemi ile karşılaşacaktır. Temiz su kaynaklarının sürekli kirlendiği, nüfusun hızla arttığı bir dünyada su israfını önlemenin ne kadar lüzumlu olduğu aşikârdır. Bu hedefin tahakkuku için fiyatlandırma mekanizmasını düşünmemek çok hayalî bir yaklaşım olacaktır. İkinci olarak; özel sektör açısından, kar maksimizasyonu birinci ölçüt olduğu için, tüketicinin suyu pahalıya satın alması noktasında fiyatlandırma sorunu ortaya çıkacaktır. Bazı ülkelerde olduğu gibi dünya, özel sektörün bu hizmeti sunması ile "su yoksulu" kavramı ile tanışacak, insanlar pahalı olan suya ulaşamadıkları için hayat kaliteleri düşecek, hatta azımsanmayacak sayıda insan, hayatını kaybedecektir.

Bu çalışmada genel kanı, içme suyunun ekonomik bir meta olmaktan çok, kamusal yönünün daha ağır olduğudur. Ancak bu kanı, fiyatlandırmanın yapılmaması anlamına gelmemelidir. Mahalli idarelerdeki fiyatlar, piyasadaki fiyatlara benzemesine rağmen, aslında kamu fiyatıdır. Çünkü bu fiyatlar arz ve talebe göre oluşmazlar. İçme suyu hizmetinin özel faydası, sosyal faydasından büyüktür. Hizmetten faydalananların mutlaka bir bedel ödemesi gerekmektedir. Sosyal faydasının da göz önüne alınmasıyla belirlenen bu bedele fiyat denmektedir (Binatlı, Varcan ve Çakır, 1994:22).

İçme suyu hizmeti, temin, taşıma ve dağıtım gibi alt yapı hizmeti kapsamında değerlendirilmektedir. Bu hizmetin etkin yürütülebilmesi için, anlamlı bir bakım onarım yatırımına ihtiyaç duyulmaktadır. Bu yatırım olmaz ise, suyun hijyenik sunulması tehlikeye girecek, içme suyunun kalitesi düşecektir. Kalitesi düşen suyun, hane

\footnotetext{
${ }^{3}$ Transparancy Statement (2006), "Water and Wastewater Prices in Metropolitan and Regional, South Australia" s:7
} 
halklarınca talebi azalacak, tüketici içme suyunu daha pahalı bir şekilde piyasadan temin edecektir (Çelen ve Bali, 2005).

Diğer taraftan içme suyu diğer erdemli mallar gibi, tüketimi sürekli özendirilecek bir mal değildir. Belli bir noktaya kadar, yani gereksinim miktarının tüketimi özendirilip, bu miktardan sonrası için de israfı önleyici bir fiyat politikası şarttır. İzlenecek fiyat politikası, tüketilecek miktarın yönetimine aracılık etmelidir. Denge muhafaza edilmelidir.

Ülkemizde içme suyu sektörü, kamunun tekeli altında bulunmakta, halkın \%99'u merkezi ya da yerel idarelerce sunulan hizmetlerden faydalanmaktadır. Alt yap1 sektörleri içinde en fazla tekel özelliği gösteren su sektöründe, en uygun kurumsal yapının ne olduğu ve fiyatlandırmanın nasıl yapılacağı noktasında fikir birliği bulunmamaktadır (DPT, 2001: 58). Dünyada su üzerinde genel kabul görmüş konulardan ilki, sağlıklı ve yeterli suya ulaşmanın insan hakkı olarak tanımlanmasıdır. İkicisi ise, sürdürülebilir bir kalkınma için, suyun bir bedel karşılığı sunulması gerekliliğidir (DPT, 2001: 59-60).

Yaşam standartları, ekonomik gelişme düzeyi ve nüfus arttıkça, suya olan talep her geçen gün artmaktadır. Talebin artmasına karşın su miktarı sabit kalmaktadır (Tüsiad, 2008: 183). Bu durum sadece yerel ve mahallî bir sorun olmaktan öte, bölgesel ve küresel anlamda ciddi bir sorun olarak çıkagelmektedir (Azevedo ve Baltar, 2005). Artan talebi karşılamak, kaliteli ve yeterli miktarda suyu sunabilmek için üç farklı yaklaşım ve mekanizma benimsenmektedir. Birincisi, uzun vadeli sabit sunum ilkesidir. İkincisi arz odaklı yönetimdir. Üçüncüsü ise talep odaklı mekanizmadır.

Uzun vadeli sabit sunum yaklaşımında çevresel ve ekonomik faaliyetler fazla olup, kamu kaynakları israf edilmektedir (Güler, 1999: 17). Halk su kaynaklarının çok ucuz olduğu kanısına kapılmaktadır. Bu yönteme göre, gereksiz su kullanımını kısmak mümkün değildir. Bedel alma ilkesinin suyun aşırı ve gereksiz kullanımını kısacağı görüşü vardır. Fatura edilen su kullanım ücretinin maliyetin altında olduğu, ancak yine de yatırımlar için bir finansman aracı olacağı varsayılmaktadır. Dolayısı ile israf az da olsa önlenmiş olacaktır. Suyun fiyatlandırılması suyun ekonomik değerini belirlemenin yanında özellikle talebin yönetilmesi tüketimin dengelenmesi ve doğal kaynakların daha etkin kullanımı açısından büyük önem arz etmektedir.

\section{LITERATÜR TARAMASI}

Literatür, "içme suyu yönetimi" ve "içme suyu fiyatlandırması" kavramları bağlamında taranmıştır. Tarımsal sulama ile ilgili yapılan çalışmalar dışlanmıştır. Geriye kalan diğer çalışmaların önemli bir kısmı "su hakk1" ile ilgili olduğu görülmüştür. Ulaşılan çalışmalar $4 \mathrm{~N} 1 \mathrm{~K}$ literatür tarama modeline göre irdelenmiştir. 


\begin{tabular}{|c|c|c|c|}
\hline Yazar, Tarih & Amaç & Yöntem & Sonuç \\
\hline Kartal, 2006 & $\begin{array}{l}\text { Son yıllarda suyun ticari bir } \\
\text { mal gibi görülmesinin, } \\
\text { insanların suya erişimini nasıl } \\
\text { etkilediğini araştırmaktır. }\end{array}$ & $\begin{array}{l}\text { Literatür } \\
\text { İncelemesi }\end{array}$ & $\begin{array}{l}\text { Su ticari bir meta olarak } \\
\text { görüldüğünde, özel sektörün bu } \\
\text { hizmeti sunmasının zor olacağ1 tespit } \\
\text { edilmiştir. }\end{array}$ \\
\hline Kılıç, 2008 & $\begin{array}{l}\text { Suya erişim sorununun nasıl } \\
\text { çözüleceği konusunda öneriler } \\
\text { sunmaktır. }\end{array}$ & $\begin{array}{l}\text { Literatür } \\
\text { İncelemesi }\end{array}$ & $\begin{array}{l}\text { Su kıtlı̆̆ı sorunun çözüm yolunun } \\
\text { özelleştirmeden geçmediği ve israfı } \\
\text { kısacak baska yolların bulunması } \\
\text { gerektiği vurgulanmıştır. }\end{array}$ \\
\hline $\begin{array}{l}\text { Eren, Bilgiç, Karlı } \\
\text { ve Miran, } 2008\end{array}$ & $\begin{array}{l}\text { Güneydoğu Anadolu } \\
\text { bölgesinde yer alan } 6 \text { ilde } \\
\text { yaşayan vatandaşların sağlıklı } \\
\text { suya ulaşmak için katlanmayı } \\
\text { kabul ettikleri fiyat tespit } \\
\text { edilmiştir. }\end{array}$ & Anket & $\begin{array}{l}\text { Çalışmanın sonunda katılımcıların } \\
\text { sağlıklı suya erişebilmek için } 6 \text { YTL'yi } \\
\text { gözden çıardıkları, bunun üzerindeki } \\
\text { bir fiyat toplam hasılayı negatif yönde } \\
\text { etkileyeceği tespit edilmiştir. }\end{array}$ \\
\hline Özsoy, 2009 & $\begin{array}{l}\text { Suyun ticari bir meta olarak } \\
\text { görülmesinin toplumsal olarak } \\
\text { yansımalarını tartışmaktır. }\end{array}$ & $\begin{array}{l}\text { Literatür } \\
\text { İncelemesi }\end{array}$ & $\begin{array}{l}\text { Suyun kamusal nitelikte bir hizmet } \\
\text { olduğu sonucuna varılmıştır. }\end{array}$ \\
\hline $\begin{array}{l}\text { Güzelsarı ve } \\
\text { Tuluay, } 2011\end{array}$ & $\begin{array}{lr}\text { Suyun } & \text { özelleştirilmesi } \\
\text { sürecinde } & \text { uluslararas1 } \\
\text { örgütlerin incelenmesidir. }\end{array}$ & $\begin{array}{l}\text { Literatür } \\
\text { İncelemesi }\end{array}$ & $\begin{array}{l}\text { Su kıtlığını çözmek için özelleştirilmesi } \\
\text { gerektiği düşüncesinin yanlış olduğu, } \\
\text { suyun ticarileşmesinin suya erişimi } \\
\text { daha zor hale getirdiği tespit edilmiştir. }\end{array}$ \\
\hline $\begin{array}{l}\text { Tutar, K1lıç ve } \\
\text { Aytekin, } 2012\end{array}$ & $\begin{array}{l}\text { Su arzı ve talebi, ekonomi } \\
\text { içindeki yeri ve dünya içme } \\
\text { suyu uygulamaları konu } \\
\text { edilmiştir. }\end{array}$ & SWOT Analizi & $\begin{array}{l}\text { Analizin sonunda, su kaynaklarının } \\
\text { yeterli olmadığ1 ve suyun ekonomik } \\
\text { bir mal olduğu ortaya konmuştur. }\end{array}$ \\
\hline Atvur, 2013 & $\begin{array}{l}\text { Dünyada su yönetimi } \\
\text { tartışmalarının geldiği son } \\
\text { noktayı ortaya koymaktır. }\end{array}$ & $\begin{array}{l}\text { Literatür } \\
\text { İncelemesi }\end{array}$ & $\begin{array}{l}\text { Su hakkı kavramının yaygınlaşmasının } \\
\text { gerektiği ortaya konmuştur. }\end{array}$ \\
\hline Çalcalı, 2014 & $\begin{array}{lrr}\text { Çalışma } & \text { Türkiye'de } & \text { şebeke } \\
\text { suyu } & \text { hizmetinin } & \text { son } \\
\text { durumunu } & \text { konu } \\
\text { edinmektedir. } & \end{array}$ & $\begin{array}{l}\text { Literatür } \\
\text { İncelemesi }\end{array}$ & $\begin{array}{l}\text { Çalışmada, Türkiye'de şebeke suyu } \\
\text { hizmetinin yönetilmesinde bağımsız } \\
\text { bir kuruluşa ihtiyaç olduğu ortaya } \\
\text { konmuştur. }\end{array}$ \\
\hline
\end{tabular}

\section{YÖNTEM VE BULGULAR}

Bu çalışmada derinlemesine görüşme tekniği kullanılmıştır. Kolayda örnekleme ile Ankara, İzmir, Manisa, Uşak, Afyon illerinde yaşayan 150 katılımcıya ulaşılmıştır. Katılımcılara önceden hazırlanan 5 soru yöneltilmiştir. Verdikleri cevaplar tarafımızdan çalışmaya dâhil edilmiştir. Çalışmada kullanılan sorular şunlardır;

1. Suya erişim sizce insan haklarından midır?

2. Belediyeler tarafından meskenlere tedarik edilen içme suyu sizce kamusal bir mal midır?

3. Meskeninizde kullandığınız suyu pahalı mı bulmaktasınız?

4. Eğer belediye başkanı olsaydınız içme suyu hizmetinin fiyatlandırmasını nasıl yapardınız? 
5. Belediyelerin sundukları içme suyu hizmeti sizce bir bedel karşılığı mı olmalı?

Birinci soruda içme suyu hizmetinin veya suya erişimin bir insanlık hakkı olup olmadığı sorgulanmıştır. Katılımcıların tamamı suyu bir insan hakkı olarak görmektedirler. Özellikle Afrika'da temiz suya erişemediği için hayatlarını kaybeden insanların varlığı konusu katılımcıların belirttikleri en önemli durum olarak gözlenmiştir. Suyun insanın temel haklarından sayılmasının sebebi erişilemediğinden ötürü insan hayatının sona ermesidir. Literatür taramasında da bu durum net bir şekilde görülmüştür. Zira içme suyu ile ilgili yapılan çalışmaların önemli bir kısmında suya erişimin insanın en önemli haklarından olduğu vurgulanmaktadır.

Katılımcılar 2. soruya net bir cevap verememişlerdir. Bu soruda, belediyeler tarafından sunulan su hizmetinin kamusal mal niteliğe haiz olup olmadığı sorulmuştur. Zira "içme suyu özel maldır" veya "içme suyu kamusal bir maldır" gibi genellemelerden kaçınmışlardır. Yapılan çalışmalarda ise içme suyunun kamusal mal olma yönünün daha ağır bastığı görülmüştür. İçme suyu hizmetinin özelleştirilmesinin sakıncaları pek çok çalışmada dile getirilmiştir. Kamusal malların en temel özellikleri; tüketiminden kimsenin dışlanmaması, fiyatlandırılamaması ve faydasının bölünememesidir. Bu özelliklere bakıldığında içme suyu hizmeti günümüz koşullarında özel bir mal görünümündedir.

3. soru suyun fiyatı ile ilgilidir. Belediyeler tarafından sunulan içme suyu hizmet fiyatının nasıl olduğu bu soruda ortaya konmak istenmiştir. Buna göre katılımcıların önemli bir kısmı, belediyelerin sundukları içme suyunu pahalı bulmadıklarını söylemişlerdir. Zira iller bazında belediyelerin içme suyu tarifeleri incelendiğinde bu durum görülmektedir. Belediyeler eliyle sunulan içme suyu hizmetinin gerçek fiyatının faturalara yansıtılmadığı düşünülmektedir. Bazı katılımcılar ise olması gerekenden pahalı bulmaktadırlar. Bu katılımcıların ortak özelliği ise, suyu hak olarak görmeleridir. Hak olan bir şeyin tüketiminden insanların dışlanmasını kabul etmedikleri için mevcut fiyat tarifelerini yüksek bulmaktadırlar.

4. soruda ise net bir cevap elde edilememiştir. Çünkü fiyatlandırma konusu için teknik bilgiler de gereklidir. Bu nedenle çalışmanın bu kısmında daha çok literatürdeki bilgilerden faydalanılmıştır. Buna göre, içme suyu kıt bir kaynak olduğu için israfın önüne geçilmesi gerekmektedir. Temiz suya ulaşmak her geçen gün daha da zor hale gelmektedir. Bedelsiz sunulan içme suyunun israfa neden olduğu birçok çalışmada vurgulanmıştır. Su israfının önüne geçilebilmesi için mutlaka bir fiyatlandırma mekanizmasının uygulanması gerektiği belirtilmektedir. Fiyatlandırma, her ne kadar özel malların özelliği olsa da, kamusal mal niteliği ağır basan içme suyu için kaçınılmaz bir gerçektir. Ancak içme suyunun gerçek fiyatı ile değil, israfı önleyecek seviyede sunulması tavsiye edilmektedir.

5. soru bir önceki sorunun devamı niteliğindedir. Bu soruda ise verilen cevaplar temelde 3 gruba ayrılmıştır. Katılımcıların bir kısmı içme suyunun bedelsiz sunulması gerektiğini ifade etmişlerdir. Başka bir kısmı ise bir bedelinin olması gerektiğini savunmuşlardır. Son kısım katılımcılar, bir insanın ulaşması gereken su miktarının bedelsiz sunulması ve fazlasının ise fiyatlandırılması gerektiğini ifade etmişlerdir. 
Uluslararası literatürde hâkim olan görüş ise, bir insanın hayatını devam ettirmesi için gereken su miktarının bedelsiz sunulmasıdır. Bu miktardan sonrası için israfı önleyecek bir fiyatlandırma mekanizmasının uygulanmasıdır.

\section{SONUÇ}

Son yıllarda tatlı ve temiz suya erişim dünya ülkelerinin en önemli sorunları arasında yer almaktadır. Özellikle birçok Afrika ülkesi ciddi anlamda su sıkıntısı yaşamaktadır. Kıt bir kaynak olması da düşünüldügünde suyun israfının önlenmesi önemli bir konudur. Temiz su kaynaklarının korunabilmesi konusunda uluslararası bazı adımların atıldığ1 gözlemlenmektedir. Ancak henüz içme suyunun nasıl bir mal olduğu konusunda fikir birliği sağlanamamıştır. Bu çalışmada içme suyunun tasnif sorunu konu edilmektedir. İçme suyunu ekonomik bir mal olarak gören bir anlayış hâkimdir. Bu anlayışın gerekçesi, kıt bir mal olan suyun fiyatlandırılması gerektiğidir. Fiyatlandırılmadığı takdirde insanların içme suyunu gereksiz kullanmalarının önü açılacaktır. Birleşmiş Milletler, Dünya Bankası ve IMF gibi kuruluşların da konuya bu açıdan baktıkları görülmektedir. Başka bir akım ise içme suyunun insanın temel haklarından olduğunu ve bedelsiz sunulması gerektiğini savunmaktadırlar.

Bu çalışmanın amacı, insanların içme suyunu nasıl bir mal olarak gördüklerinin tespit edilmesidir. Çalışmada derinlemesine görüşme tekniği kullanılmıştır. Ankara, İzmir, Manisa, Uşak, Afyon illerinde yaşayan 150 katılımcı belirlenmiştir. Katılımcılara önceden belirlenmiş mülakat soruları sorulmuştur. Örneğin, suya erişimin insanın temel haklarından olup olmadığı sorulmuş̧tur. Ayrıca kendilerine sunulan içme suyu hizmetinin bedelini nasıl buldukları sorusu da yöneltilmiştir. Sonuç olarak katılımcıların içme suyunu insani bir hak olarak gördükleri tespit edilmiştir. Suyun bütünü ile bedelsiz sunulmasının sakıncalı olabileceğini ifade etmişlerdir. Çalışmada en iyi yöntemin, asgari su miktarının her insana bedelsiz sunulması ve diğer kısmının ise israfın önüne geçmek adına fiyatlandırılması gerektiği sonucuna ulaşılmıştır.

\section{KAYNAKÇA}

Akalın G. (2003). Belediyelerin Ekmek Piyasasına Müdahalesi, Piyasa Dergisi, 5:42-43.

Ataay F. (2003). Doğal Tekellerde Özelleştirme Sorunu, Kamu Yönetimi Dünyası Dergisi, 4(16): 34-38.

Atvur S. (2013). Küresel Su Politikalarında Temel Tartışmalar, C.Ü. İktisadi ve İdari Bilimler Dergisi, 14(1): 315-334.

Aykan M. (2006). IMF ve Dünya Bankası Su Politikaları, Çok Uluslu Şirketlerin Türkiye' deki Uygulamaları, TMMOB Su Politikaları Kongresi (2006), s. 36-376

Bakker, K. (2007). The "Commons" Versus The "Commodity": Alter-Globalization, AntiPrivatization and The Human Right to Water in The Global South. Antipode, 39(3): 430455. 
Biswas, Asit K. (1997). Water Development and The Environment. International Journal of Water Resources Development 13(2): 141-168.

Binatlı C., Varcan N. ve Çakır, T. (1994) Mahalli İdareler Ekonomisi, Anadolu Üniversitesi, Açık Öğretim Fakültesi, Kamu Yönetimi 212, Yayın No:807, Eskişehir, s:22

Çalcalı Ö. (2014). Su Sektörünün Kamusallık Niteliğinin Dönüşümü: Türkiye'deki Şebeke Suyu Endüstrisi İçin Bir Değerlendirme, Akademik Araştırmalar ve Çalışmalar Dergisi, 10: 111-129.

Çelen M. ve Bali B. (2005). Alt Yapı Yatırımlarına Özel Sektör Katılımının Fiyatlama Politikası Üzerine Etkisi, Marmara Üniversitesi, İIBF Dergisi, 20: 217-245.

Castro, José Esteban (2008). Neoliberal Water and Sanitation Policies as a Failed Development Strategy Lessons from Developing Countries. Progress in Development Studies, 8.(1):63-83.

Çakal R. (1996), Doğal Tekellerde Özelleştirme ve Regülasyon, DPT Uzmanlık Tezi, DPT Yayın No:2455, Ankara

Çiçek E. (2009). Kar Mı İnsan Hakkı Mı Bir İnsan Hakkı Olarak Su Hakkının Dava Edilebilirliği, TBB Dergisi, 80: 182-228

De Azevedo, L. G. T., and Baltar, A. M. (2005). Water Pricing Reforms: Issues And Challenges of Implementation. International Journal of Water Resources Development, 21(1): 19-29.

Diler, Ö. (2008). Suyun Fiyatlandırma Politikası Çerçevesinde Sanal Su Yaklaşımı Üzerine Bir Değerlendirme. Yayınlanmış Y. Lisans Tezi, S.D.Ü Diss. Sosyal Bilimler Enstitüsü

Eren, G., Bilgiç, A., Karli, B., ve Miran, B. (2008). Gap Bölgesi'nde Kaliteli İçme Suyunun Fiyatlandırılmasına Etki Eden Faktörler. Turkish Journal of Agricultural Economics, 14(2): $67-74$

Gleick, Peter H. (1993). Water and Conflict: Fresh Water Resources And International Security. International Security (1993): 79-112.

Gökdemir B. (2008). Küresel Su Krizine Çözüm Arayışları: Şebeke Suyu Hizmetlerine Özel Sektör Katılımı, Dünya Örnekleri Işığında Türkiye İçin Öneriler, TUSİAD, Yayın No: T/2008-09/470, İstanbul

Görer, N. (2001). İçme Suyu ve Kanalizasyon Sektöründe İzlenen Politikalar Üzerine Bir Değerlendirme, Çă̆daş Yerel Yönetimler, 10(2):18-30

Güzelsarı, S. ve Tuluay F. N. (2011). Küresel Su Yönetimi ve Suyun Ticarileştirilmesi. Abant İzzet Baysal Üniversitesi Sosyal Bilimler Enstitüsü Dergisi 22(1): 54-83.

Hubert H.G. Savenije and Pieter van der Zaag (2002). Water as An Economic Good and Demand Management paradigms With Pitfalls, Water International, 27(1): 98-104.

Irujo, Antonio Embid 2007). The right to water. Water Resources Development, 23.2: 267283. 
Kartal, F. (2006). Suyun Metalaşması, Suya Erişim Hakkı ve Sosyal Adalet. Su Politikaları Kongresi, 2: 478-485.

Kılıç, S. (2008). Küresel İklim Değişikliği Sürecinde Su Yönetimi. İstanbul Üniversitesi Siyasal Bilgiler Fakültesi Dergisi, (39), 161-186.

Özsoy, S. (2009). Su ve yaşam: Suyun toplumsal önemi (Doctoral dissertation, Yüksek Lisans Tezi, T.C. Ankara Üniversitesi, Sosyal Bilimler Enstitüsü, Çalışma Ekonomisi ve Endüstri İlişkileri Anabilim Dalı, Ankara).

Solanes, M., and Gonzalez-Villarreal, F. (1999). The Dublin Principles for Water as Reflected in A Comparative Assessment at Institutional and Legal Arrangements for Integrated Water Resources Management (p. 17). Global Water Partnership Technical Advisory Committee.

Tepe B. ve Ardıyok Ş. (2004). Devlete Yeni Rol: Regülasyon, Amme İdaresi Dergisi, 37(1): $105-130$.

Tutar, F., Kılıç, N., ve Aytekin, S. (2012). Türkiye'de Suyun Ekonomik Analizi. Adryaman Üniversitesi Sosyal Bilimler Enstitüsü Dergisi, 2012(9), 231-246.

Van der Zaag, Pieter, and Hubert HG Savenije (2000). Towards improved management of shared river basins: lessons from the Maseru Conference. Water Policy 2(1): 47-63. 